\title{
PHYTOCHEMICALS AND ORGANIC COMPOUNDS OF TWO NIGERIAN INSECTICIDAL PLANTS
}

\author{
E. O. Emeribe \\ Department of Crop Science and Biotechnology, \\ Faculty of Agriculture and Veterinary Medicine, Imo State University, Nigeria \\ Corresponding authors email: rightagrochem@yahoo.com
}

\begin{abstract}
The samples of two Nigerian insecticidal plants Alligator pepper (Aframomum melegueta Zing) and Black pepper (Piper nigrum L.), were analyzed for their phytochemical composition and organic compounds. The evaluations were aimed at the fundamental scientific basis for the use of these plants by determining their chemical constituents as well as quantifying the percentage of phytochemicals and organic compounds present in the seeds of Piper nigrum and Aframomum melegueta.The experiment was conducted in the Chemistry laboratory of Michael Okpara University of Agriculture Umudike, between March-April, 2018. Results revealed the presence of bioactive constituents comprising: Alkaloids (85.67-50.13 mg 100-1g), Flavonoids (4.02-24.56 mg 100-1g), Saponins (7.52-5.51 mg 100-1g), Tannins (0.22-17.79 mg 100-1g), and Phenols (0.71-2.01 mg 100-1 $\mathrm{g})$. The two plant extracts contained organic compounds $\mathrm{OH}, \mathrm{COOH}$ and $C=O$ respectively as functional groups and alcohol, phenol, carboxylic acid and ketones as compound types detected, with aromatic compounds found in Aframomum melegueta. The bioactive compounds were responsible for the insecticidal related properties of Piper nigrum and Aframomum melegueta. The detected bioactive compounds proved the importance of the two plants from insecticidal point of view and invites additional research for characterization of these phytochemicals and their proper evaluation for pest control in Nigeria.
\end{abstract}

Keywords: Aframomum melegueta, bioactives, Piper nigrum, Phytochemicals https://dx.doi.org/10.4314/jafs.v16i1.1

\section{INTRODUCTION}

In Nigeria, many indigenous plants are used as spices, food and medicine or as pest control agents (Emeribe et al., 2016). A great number of these plants are traditionally noted for their medicinal and pesticide properties (Okwu, 2005). These plants exhibit a wide range of biological and pharmacological activities, such as anti-inflammatory, anti-bacterial, and anti-fungal properties (Okwu, 2005). Extracts from the leaves, roots, barks, seeds and fruits of these plants are used in the preparation of syrups and infusions in traditional medicine as a cough suppressant and in the treatment of liver cirrhosis, hepatitis and insecticides for crop pests either in the field 
or store (Iwu, 1986; Ogu, 1995; Okwu, 2005; Emeribe et al., 2016). It is generally assumed that the active constituents contributing to these protective effects are the phytochemicals, vitamins and organic compounds which are present in a variety of plants utilized as important components of both human and animal diets. These include herbs, fruits, seeds and vegetables. Herbs and spices are harmless sources for obtaining natural antioxidants (Okwu, 2004; Kim et al., 1994; Hetoget al., 1993). Phytochemicals which posses many ecological and physiological roles are widely distributed as plant constituents. Plants produce them as secondary metabolites, which are not directly involved in the process of growth, but act as deterrents to insect microbial attack. Woody plants can synthesize and accumulate in their cells a great variety of phytochemicals like alkaloids, flavonoids, tannins, cyangenic, glycosides, saponins, phenols, lignin and lignan (Okwu and Ekeke; 2003, Emeribe et al., 2016).

No crop production programme succeeds without a sound, well planned crop protection scheme (Ngoka, 1997). For decades, the pest control policy in Nigeria has been dependent upon the use of synthetic pesticides. They are known to have undoubted benefits, the environmental hazards associated with their application and the development of insect resistance has become a major concern in Nigeria and other developing countries, where majority of farmers and pesticide users are not trained in the safe handling and application of these chemicals (Ohazurik et al., 2003; Halima, 2008; Asma et al., 2014; Emeribe et al., 2015). Regrettably, these chemicals are still used in plant pest control even though they are no longer officially permitted in most countries. Therefore, a need arises to investigate the potency of plant products that are effective, readily available, cheap and non-toxic for the protection of plants and stored products (Ogendo, 2004; Ohazurike et al., 2003; Amal et al., 2012). Botanical insecticides are important alternatives that can minimize or replace the use of synthetic pesticides as they possess an array of properties including toxicity, repellent, anti feedant and growth regulatory activities against different pests (Lalah and Wandiga, 1996; Okwu, 2003). About 400,000 plant species were reported to possess pest control properties, out of which very little number is being used for insect control purposes. Fortunately, most of active plant species in the world were thought to be found in tropical countries (Whitehead and Bowers, 1983; Ahmed and Stoll, 1996). Nigeria is considered one of the richest African countries in floral diversity which needs to be studied for the constituents of their bioactive compounds in the control of pests and diseases. (Emeribe et al., 2016).

Alkaloids are amines produced by plants, they are derivatives of amino acid and many have a bitter taste (Okwu, 2005). Some of the phytochemicals contained in plants are alkaloids which are toxic to man and most of them possess dramatic physiological activities, hence they are widely used in medicine (Harbone, 1973). Saponins are glycosides with distinctive fuming characteristics, bitter and reduce the palatability of livestock feeds. Several types of phenolic acids, hydrolysable tannins and flavonoids show anti-carcinogenic and anti-mutagenic effects (Urquianga and Leighton, 2000). Several studies have shown that in addition to their antioxidant 
protective effect, polyphenols, particularly flavonoids inhibit the initiation, promotion and progression of tumors (Okwu, 2004; Urquianga and Leighton, 2000). In recent times, plant flavonoids have attracted attention as potentially important chemo-protective agents (Okwu, 2004, Hetog et al., 1993). Moreover, naturally occurring phytochemicals are potential antiallergic, anti-carcinogenic, antiviral, antioxidant and insecticidal agents (Close and McArthur, 2002).

The insecticidal approach in agriculture had its beginning in the use of plant materials. Many of the oldest and most common pesticides such as nicotines, pyrethrines and rotenone were derived from plants. However, much of the plant kingdom still remains unexplored for possible exploitation against direct and indirect effects on plants and seeds (Ohazurike et al., 2003; Emeribe et al., 2015).

Several Nigeria tribes are known to mix a wide range of plants to control plants and storage pests. The species used in this way include, Anona senegalensis Pers, Ocimum americanum L, Nicotiana spp and Ocimum grattisimum (Giles, 1964). Shaaya et al., (1997), stated that vegetable oils and peanut oil were effective as protectants against bruchid beetles. Kalivonic et al., (1997), investigated the insecticidal activity of oil extract from bay leaf and ground dust of rosemary on Sitophilus granaries in wheat. They reported a significant mortality in treated grains. Ogendo et al., (2004); Umoetuk et al., (2004), noted that natural plant products protected maize grains from having exit holes, revealed residual toxicity after re-inoculation and were ovicidal in action. However, oils and crude fibres of several plant species have been shown to have no adverse effects on the germination of maize, sorghum, pigeon pea and green gram (Ogendo et al., 2004), crude extracts of Moringa oleifera and Ocimum gratissimum leaf showed repellent action on cashew and mango fruits against Musca domestica (Emeribe et al., 2017). Black pepper (Piper nigrum L), Piperraceae and Alligator pepper, (Aframomum melegueta Zing), Zingiberaceae are such plants that poses insecticidal properties. They are readily available in most rural communities of south east zone of Nigeria and other West African countries. They are under-utilized, neglected but can be improved. Therefore, this study investigated the fundamental scientific basis for the use of these plants by determining the chemical constituents as well as quantifying the percentage of phytochemicals and organic compounds present in the seeds of Piper nigrum and Aframomum melegueta.

\section{MATERIALS AND METHODS}

Study Location and sample collection: The experiments were conducted between March-April, 2018, at the Chemistry laboratory of Michael Okpara University of Agriculture Umudike, Abia State, Nigeria. Seeds of Piper nigrum and Aframomum melegueta were bought from Eke Atta market in Ikeduru Local Government Area of Imo state, Nigeria 
Sample preparation: Ripe seeds of $P$. nigrum and A. melegueta were each weighed $(1 \mathrm{~kg})$. The plant samples were sun dried and ground into uniform powder using Thomas- Wiley machine and stored in airtight bottles till required for analysis.

\section{Phytochemical Determination and Infrared Spectrometer (Scan)}

Phytochemical Screening:- After drying and grinding the test plants, !0g each of P. nigrum and A. melegueta were defatted, screened in the laboratory for the presence of phytochemicalsAlkaloids, Tannins, Saponins, Flavonoids and phenols.

Preparation of fat free sample: $2 \mathrm{~g}$ of each of the samples were defatted with $100 \mathrm{ml}$ of diethyl ether using a Soxhlet apparatus for 2 hours.

Alkaloid Determination: This was done using the method described by Harbone, (1973). 5g each of black pepper and alligator pepper samples were weighed into a $250 \mathrm{ml}$ beaker respectively. $200 \mathrm{ml}$ of $10 \%$ acetic acid in ethanol was added to each of the beaker and covered to stand for $4 \mathrm{hrs}$. This was filtered and the extract was concentrated using a water-bath to onequarter of the original volume. Concentrated ammonium hydroxide was added drop wise to the extract until the precipitation was complete. The whole solution was allowed to settle and the precipitate was collected and washed with dilute ammonium hydroxide solution and then filtered. The residue is the crude alkaloid, which was weighed.

Determination of total phenols by spectrophotometric method: This was extracted using the method described by Harbone, (1973). The fat free sample was boiled with $50 \mathrm{ml}$ of ether for the extraction of the phenolic component for 15 minutes. $5 \mathrm{mls}$ each of the extracts were pipetted with a $50 \mathrm{ml}$ flask, and then $10 \mathrm{ml}$ of distilled water added. $2 \mathrm{ml}$ of ammonium hydroxide solution and $5 \mathrm{ml}$ of concentrated amyl alcohol were also added. The samples were made up to mark and left to react for 30 minutes for colour development. The absorbance of the solution was read at $505 \mathrm{~nm}$-wave lengths using a spectrophotometer. Standard solutions of phenol were prepared at $0.0,2.00,4.00,6.00,8.00$ and $10.00 \mathrm{ppm}$ respectively, with the same treatment. Calibration curves of the absorbance values versus concentration of the standard were constructed and the value of phenol in the samples calculated.

Tannin Determination: This was determined using the method described by Van Burden \& Robison, (1981). 50mg each of the samples of Piper nigrum and Aframomum melegueta were weighed into $100 \mathrm{ml}$ plastic bottles. $50 \mathrm{ml}$ of distilled water was added and shaken for $1 \mathrm{hr}$ in a mechanical shaker. This was filtered into a $50 \mathrm{ml}$ volumetric flask and made up to the mark. Then $5 \mathrm{ml}$ of the filtrate was pipetted out into a tube and mixed with $3 \mathrm{ml}$ of $0.1 \mathrm{M} \mathrm{FeCl}_{3}$ in $0.1 \mathrm{~N} \mathrm{HCl}$ and $0.008 \mathrm{M}$ potassium ferrocyanide. The absorbance was measured in a spectrophotometer at $120 \mathrm{~nm}$ wavelength within 10 minutes. A blank sample was prepared and the colour also 
developed and read at the same wavelength. A standard was prepared using tannin acid to get $100 \mathrm{ppm}$ and measured.

Saponin Determination: This was determined according to the method of Obadoni and Ochuko, (2001). $20 \mathrm{~g}$ of each plant samples were dispersed in $200 \mathrm{ml}$ of $20 \%$ alcohol. The suspension was heated over a hot water bath for $4 \mathrm{hrs}$ with continuous stirring at about $55^{\circ} \mathrm{C}$. The mixture was filtered and the residue re-extracted with another $200 \mathrm{ml}$ of $20 \%$ ethanol. The combined extracts were reduced to $40 \mathrm{ml}$ over water bath at about $90^{\circ} \mathrm{C}$. The concentrate was transferred into a $250 \mathrm{ml}$ separatory funnel and $20 \mathrm{ml}$ of diethyl ether was added and shaken vigorously. The aqueous layer was recovered while the ether layer was discarded. The purification process was repeated. $60 \mathrm{ml}$ of $\mathrm{n}$-butanol was added. The combined $\mathrm{n}$-butanol extracts were washed twice with $10 \mathrm{ml}$ of $5 \%$ aqueous sodium chloride. The remaining solution was heated in a waterbath. After evaporation, the samples were dried in the oven to a constant weight. The saponin content was calculated in percentage.

Flavonoid Determination: This was determined by the method described by Bohman and Kocipai, (1974). $5 \mathrm{~g}$ of the plant samples were extracted repeatedly with $100 \mathrm{ml}$ of $80 \%$ aqueous methanol at room temperature. The whole solution was filtered through Whatman filter paper No. $42(125 \mathrm{~mm})$. The filtrate was later transferred into a crucible and evaporated into dryness over a water bath and weighed to constant weight.

Infrared Scan: Pure samples measuring $10 \mathrm{mls}$ each of Piper nigrum and Aframomum melegueta were analyzed for infrared spectroscopy. This technique was applied to identify the compounds and to investigate the composition of Black pepper ( $P$. nigrum) and Alligator pepper (A. melegueta) The infrared portions of the electromagnetic spectrum of Black pepper and Alligator pepper were carried out based on three regions, the near, the rear, mid and far infrared, named for their relation to the visible spectrum. The far infrared (approximately $400-10 \mathrm{~cm}^{-1}$ ), lying adjacent to microwave region, has low energy and was used for rotational spectroscopy. The mid infrared (approximately $400-400^{-1}$ ) was used to study the fundamental vibrations and associated rotational-vibrational structure, whilst the higher energy near the -IR (14,000 $4000 \mathrm{~cm}^{-1}$ ) was used to excite overtone or harmonic vibrations. Infrared spectroscopy was carried out on Black pepper and Alligator pepper because their chemical bonds have specific frequencies at which they vibrate corresponding to energy levels. In order to measure the samples, a beam of infrared light was passed through the samples, and the amount of energy absorbed was recorded by using a fourier transformed instrument to measure all wave lengths at once. From this, a transmittance or absorbance spectrum was plotted which showed the wavelengths, the samples absorbed by the IR and allowed an interpretation of which bonds were present. 


\section{RESULTS}

The phytochemical constituents of Piper nigrum and Aframomum melegueta were as shown in (Table 1). The concentration of alkaloids was higher in A. melegueta $(85.67 \pm 0.820)$ than $P$. nigrum, which contained (50.13 \pm 0.820$)$. P. nigrum contained more flavonoids (24.56 \pm 0.820$)$, tannin $(17.79 \pm 0.820)$ and phenols $(2.01 \pm 0.820)$ while A. melegueta contained flavonoids (4.02 $\pm 0.818)$, tannins $(0.211 \pm 0.818)$ and phenols $(0.71 \pm 0.818)$ respectively. More saponins were

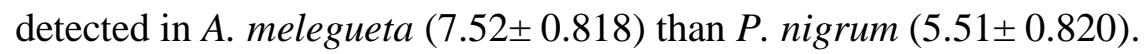

Infrared scan of $P$. nigrum showed that at 3440 wave length, which was (broad), the functional group identified was $\mathrm{OH}$ radical and compound types observed were alcohol and phenol. At 2920 wavelength, (which was narrow), the functional group identified was $\mathrm{COOH}$ radical and the compound type was carboxylic acid. At 1680 wavelength, (which was narrow), the functional group identified was $\mathrm{C}=\mathrm{O}$, which depicted a compound type known as Ketones (Table 2 and Fig. $1)$.

Infrared scan of A. melegueta showed that at 3440 wavelength, (which was broad), the functional group identified was $\mathrm{OH}$ radical and the compound types were alcohol and phenol. At 2920 wavelength (which was narrow), the functional group identified was $\mathrm{COOH}$ radical, which depicted the presence of carboxylic acid. At 1680 wavelength which was (narrow), the functional group identified was double bond $=\mathrm{C}=\mathrm{O}$, which depicted presence of ketones. At 1600 wavelength (which was also narrow), the functional groups identified were single and double bonds and the compound type was aromatic in nature. Finally, at 1500 wavelength (which was also (narrow) the functional group still contained both single and double bond with aromatic type of compound (Table 3 and Fig. 2).

\section{DISCUSSION}

Black pepper and Alligator pepper are rich in phytochemicals such as Alkaloids, Flavonoids, Saponins, Tannins and Phenols. (Tables 1 and 2). Alkaloids ranked the most efficient and therapeutically significant plant substance. Pure isolated plant alkaloids and their synthetic derivatives are used as basic medicinal agents for their analgesic, antispasmodic and bacterial effects. They exhibit marked phytochemical activity when administered to animal (Okwu, 2004). The high alkaloid content in A. melegueta and P. nigrum, could be partly responsible for the bitter principle associated with in P. nigrum and A. melegueta seeds. Moreso, alkaloids on acid base titration are poisonous and this could have been responsible for their insecticidal properties (Okwu, 2000 and 2004). The biological functions of flavonoids include protection against allergies, inflammation, free radicals, platelets aggregation, hepatoxins and tumors (Okwu, 2000 and 2004). Flavonoids represent the most common and widely distributed groups of plant phenolics. The presence of phenolic compounds in the seeds of P. nigrum and A. melegueta 
indicate that plants might be antimicrobial agents. This is because phenols and phenolic compounds have been extensively used in disinfections and remain the standard with which other bactericides are compared (Okwu, 2004). Phenol is used as a cleaning agent (Urquianga and Leighton, 2000). Extracts from P. nigrum and A. melegueta have potent antiseptic or bacterial and insecticidal properties. These findings supported the use of $P$. nigrum and $A$. melegueta in the control of weevils in grains (Emeribe et al., 2015 and 2016). Tannins have astringent and bitter properties. These effects can be instantaneous and can have a delayed response related to anti-nutritional or toxic effects. (www.wikipedis.org/wiki/tannins). P.nigrum and A. melegueta have some quantities of Saponin. Some of the general characteristics of Saponin include formation of foams in aqueous solutions, hemolytic activity, cholesterol binding properties and bitterness. These properties reduce their palatability in livestock feeds. Certain pasture which contain substantial quantities of Saponins result in life threatening toxicities for certain animal species (www.wikipedis.org/wiki/saponins). The repellent and insecticidal properties exhibited by the two test plants could be linked to the presence of phytochemicals. The astringent, bitter and poisonous properties could be responsible for their insecticidal action. This agreed with Okwu, (2000, 20004), Ahmed and Stoll, (1996), Close and Mc Arthur, (2002) that plants posses' phytochemicals in different concentrations that protect the plants from external influence (Tables 2 and Figure 1).

The results of the infrared scan on $P$. nigrum revealed some functional groups. At wavelengths (3440) broad, $(\mathrm{OH})$ was identified, at 2920 (narrow) and 1680 (narrow), $(\mathrm{C}=\mathrm{O})$ was identified. The compound types at (3340) were alcohol and phenol, at (2920), was carboxylic acid and at (1680) was ketones. The compounds identified on these wavelengths, can cause lethal effects on S. zeamais. These compounds are poisonous and posses bitter taste properties which could be insecticidal. These were in line with (Okwu, 2000 and 2004) which stated that organic compounds like alcohols, carboxylic acid, double bond ketones can exert insecticidal, fungitoxic and antimicrobial activities on pests and diseases. In the case of A. melegueta the infrared scan also revealed some functional groups and compounds as shown in (Table 3 and figure 2). At wavelengths of 3440 (broad), 2920 (narrow), 1780 (narrow), 1600 (narrow) and 1500 (narrow), the functional groups were, $\mathrm{OH},-\mathrm{COOH},=\mathrm{C}=\mathrm{O}$, and aromatic compounds respectively. The compound types were phenol, alcohol, carboxylic acid, ketones and aromatic compounds, respectively These compounds possess antimicrobial, fungitoxic and pesticidal properties on pests and diseases. Since they have bitter taste and can permeate membranes, it tallied with the work done by Okwu, (2004) that organic compounds extracted from plant materials like Garcinia cola and Aframomum melegueta were antimicrobial, antifungal and insecticidal.

\section{CONCLUSION}

The adopted chemical approach of phytochemical and other bioactive compounds analyzed from P. nigrum and A. melegueta seemed to be reasonable for this preliminary screening, and gave

Journal of the Faculty of Agriculture and Veterinary Medicine, Imo State University Owerri website: www ajol.info 
comparative information about the studied plants. Since these phytochemical classes and the bioactive compounds generally contain diversified active compounds, hence more advanced analysis is important for further bioassay and characterization to determine the active ingredients.

Journal of the Faculty of Agriculture and Veterinary Medicine, Imo State University Owerri website: www ajol.info 


\section{REFERENCES}

Ahmed, S. and Stoll, G. (1996). Biopesticides. Pages 52-79. In: Biotechnology, building on farmers' knowledge. Eds. Bunderst, Hevenkort, B. and Hiemestra, W. Macmillan, Netherlands B.V 57-59, 240.

Amal, E. E., Zuhair A. A. and Abdalla A. S. (2012). Phytochemical screening of important secondary metabolites in some extracts of two Sudanese plants Global Advanced Research Journal of Environmental Science and Toxicology 1(8), 199-202.

Asma K. M., Abdalla A. S., Suad M. B. and Mokhtar M. M. (2014).Combined insecticidal effects of some botanical extracts against the khapra beetle (Trogoderma granarium everts). Research Journal in Engineering and Applied Sciences 3(6) 388-393.

Boham, B. A. and Kocipai, A. C. (1974). Flavonoids and Condessed Tannins from leaves of HawaianVaccinium vaticulatum and V. calianium. Pacific science, 48: 458-463.

Close, D. C. and Mc Arthur, C. (2002). Rethinking the role of many plant phenolics-protection from photo damage. Oikos 99: 166-172.

Emeribe, E. O., Ohazurike, N. C and Okorie, H. A. (2015). Pesticidal Potentials of Seed Extracts of Black Pepper (Piper nigrum L) in the control of Maize grain weevil (Sitophilus zeamais Mots) in storage. J. of Agric \& Food Sci., 13(2) : 1-16

Halima, T. A. (2008). A key note address by the Honourable Minister, Federal Ministry of Environment, Housing and Urban Development, Arc.Mrs Halima TayoAlao on sensitization workshop on pesticide utilization organized by the Consumer Protection Council at Ibadan, Oyo State on the $17^{\text {th }}$ June 2008. Pp2-3.

Harborne, J. B. (1973). Phytochemical methods. Chapman and Hall, London. Pp. 110 -113.

Hertog, M. G. I., Feskeen, E. J. M, Hokman, C. H and katan, A. (1993). Dietary antioxidant Flavonoids and risks of coronary heart disease, de zutphen elderly study. Lancet, 342: 2007-1011.

Giles, P. H. (1964). The storage of cereals by farmers in Northern Nigeria. Tropical Agriculture. 42: 197-212.

Kalivonic, I. Martincic, J. Rozman, V. and Guberac, V. (1997). Insecticidal activities of substances of plant origin against stored product insects. Ocharana - Rostlin, 33(2): 135142

Kim, S. Y, Kim, J. I. I, Kim, S. K, Oh, M. J. and Jung, M. Y. (1994). Antioxidant activities of selected oriental herb extracts J. Am oil Chem Soc 71: 633-640.

Lalah, J. O. and Wandiga, S. O. (1996). The persistence and fate of melathion residues in stored beans (Phaseolus vulagris L.) and maize (Zea mays L.) Pesticide science, 46(3): 215-220.

Ngoka, D. A. (1997). Crop Production in the Tropics. Theory and Practice. Alphabet Nigeria Publishers, Owerri, Nigeria. Pp. 172.

Journal of the Faculty of Agriculture and Veterinary Medicine, Imo State University Owerri website: www ajol.info 
Obadoni, B. O. and Ochuko, P. O. (2001). Phytochemical studies and comparative efficacy of the crude extract of some homeostatic plants in Edo and Delta state of Nigeria. Journal of pure and applied science 8: 203-208.

Ogendo, J. O., Belmain, S. R., Waiker, D. J. and Musandu, A. A. (2004). Effect of insecticidal plant materials Lantana camara L. and Tephrosia vogelli Hook on the quality parameters of stored maize grains. The Journal of Food Technology in Africa 9(1): 29-36.

Ohazurike, N. C., Onuh, M. O., Emeribe, E. O. (2003). The use of seed extract of the physic Nut (Jatropha curcas L.) in the control of maize weevil (Sitophilus zeamais Mots) in stored maize grain (Zea mays L.). Global Journal of Agricultural Sciences, 2(2): 86-88.

Okwu, D. E. and Ekeke, O. (2003). Phytochemical screening and mineral composition of chewing sticks in South Easthern Nigeria. Global Journal of Pure and Applied Sciences 9: 235-238.

Okwu, D. E. (2004). Phytochemicals and vitamin content of indigenous species of the South Eastern Nigeria. Journal of Sustainable Agricultural Environment. 6(1): 30-37.

Okwu, D. E. (2005). Phytochemical, vitamins and mineral content of two Nigerian medicinal plants. International Journal of Molecular Medicine and Advanced Science 1(4): 375381.

Shaaya, E., Kostjukovski, M., Eilberg, J. and Sukpakarn, C. (1997). Plant oils as fumigants and contact insecticides for the control of stored products insects. Journal of Stored Products Resource, 33(1):7-15.

Urquianga, I and Leighton, F. (2000). Plant Polyphenol antioxidants and oxidative stress. Biological Research 33:159-165.

Umoetok, S. B. A., Oku, I. E. and Ukeh, D. A. (2004). Reduction of damage caused to stored cowpea (Vigna unginiculata L.) seeds by the bean bruchids (Callosobruchus maculatus F.) using plant products. Journal of Food Technology, 2(4):192-194.

Van-Burden, T. P. and Robinson, W. C. (1981). Formation of complexes between protein and tannin acid. Journal of Agricultural Food Chemistry, 1:77-82.

Whitehead D. L. and Bowers W. S. (1983). Natural products for innovative pest management (Current Themes in Tropical Science), 1st ed. Oxford, New York, Pergamon Press. 550pp.

www.wikipedis.org/wiki/tannins. 2016

www.wikipedis.org/wiki/saponins. 2016

\section{ACKNOLEDGEMENTS}

The authors thank late Prof. D.E Okwu of the Dept of Chemistry, Michael Okpara University of Agriculture Umudike, Abia State and Staff of Teaching and Research farm, Imo State University Owerri, Imo State Nigeria for their kind assistance in this study. 


\section{APPENDIX}

Table 1: Phytochemical constituents of the seeds of Piper nigrum and Aframomum melegueta on dry weight basis expressed as $\mathrm{mg} 100{ }^{1} \mathrm{~g}$

\begin{tabular}{lll}
\hline Phytochemical constituents & Piper nigrum & Aframomum melegueta \\
\hline Alkaloids & $50.13 \pm 0.820$ & $85.67 \pm 0.818$ \\
Flavonoids & $24.56 \pm 0.820$ & $4.02 \pm 0.818$ \\
Saponins & $5.51 \pm 0.820$ & $7.52 \pm 0.818$ \\
Tannins & $17.79 \pm 0.820$ & $0.22 \pm 0.818$ \\
Phenols & $2.01 \pm 0.820$ & $0.71 \pm 0.818$ \\
\hline
\end{tabular}

Values are means \pm SD of five determinations

Table 2: Infrared scan of $P$. nigrum

\begin{tabular}{lll}
\hline Infrared $(\mathrm{cm}-1)$ & Functional group & Compound type \\
\hline 3440W (broad) & $\mathrm{OH}$ & Alcohol, Phenol \\
2920W (narrow) & $\mathrm{COOH}$ & Carboxylic acid \\
1680W (narrow) & $\mathrm{C}=\mathrm{O}$ & Ketones \\
\hline
\end{tabular}

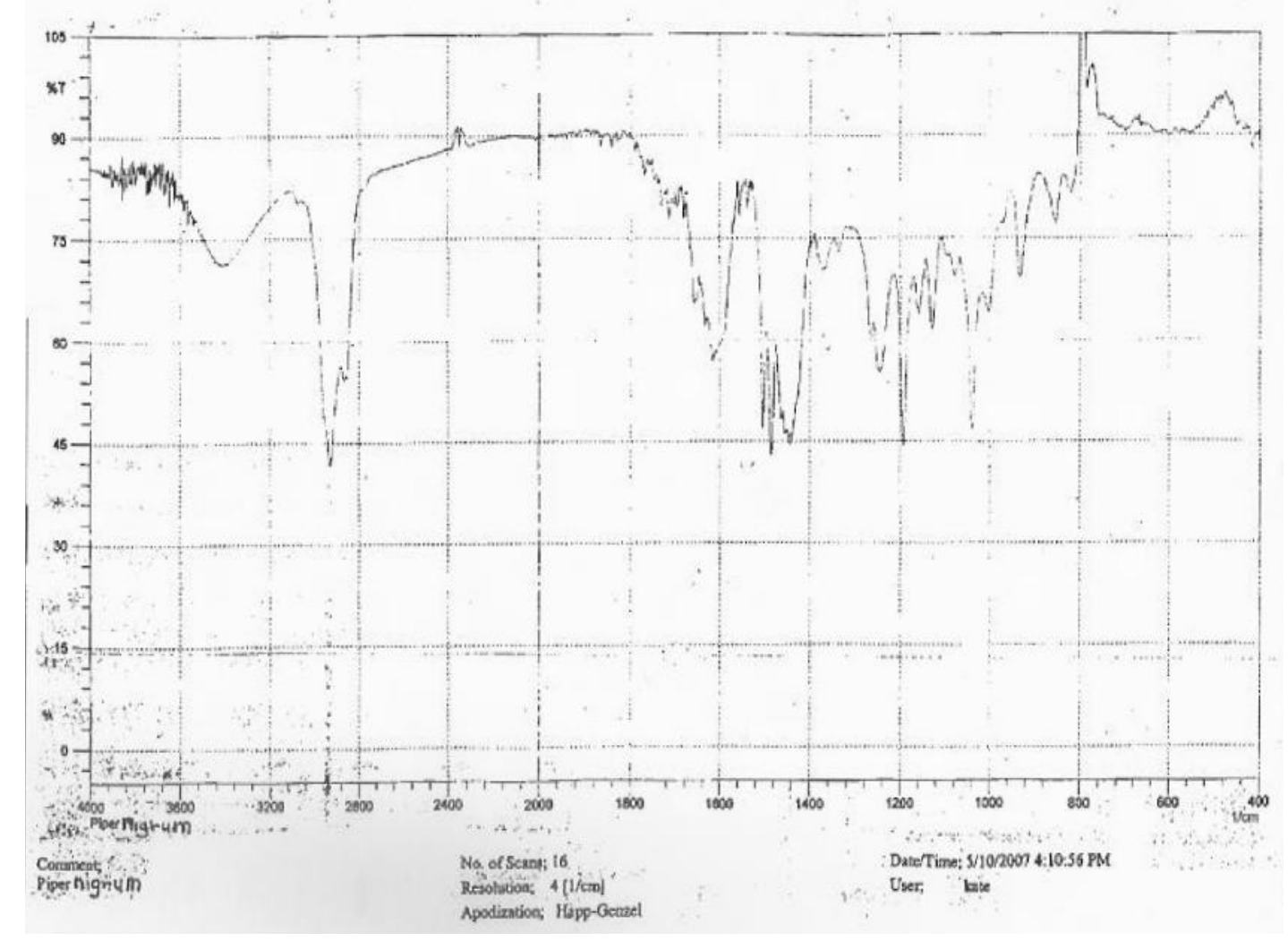

Figure 1: Infrared spectroscopy of Piper nigrum

Journal of the Faculty of Agriculture and Veterinary Medicine, Imo State University Owerri website: www ajol.info 
Table 3: Infrared scan of $A$. melegueta

\begin{tabular}{lll}
\hline Infrared $\left(\mathrm{cm}^{-1}\right)$ & Functional group & Compound type \\
\hline 3440W (broad) & $\mathrm{OH}$ & Alcohol, phenol \\
2920W (narrow) & $\mathrm{COOH}$ & Carboxylic acid \\
1680W (narrow) & Ketones \\
1600W (narrow) & Aromatic \\
1500W (narrow) &
\end{tabular}

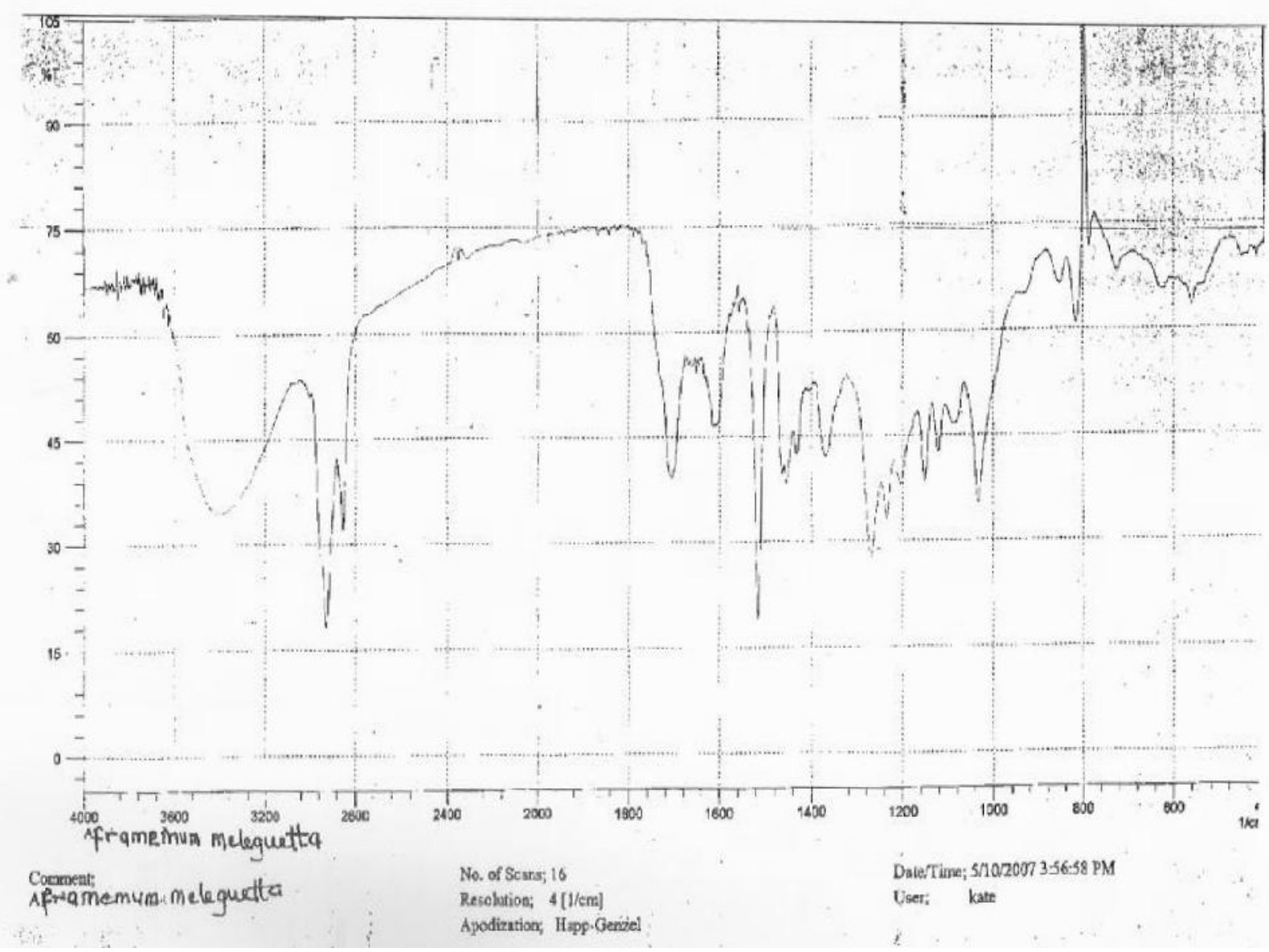

Figure 2: Infrared spectroscopy of Aframemum melegueta

Journal of the Faculty of Agriculture and Veterinary Medicine, Imo State University Owerri website: www ajol.info 